\title{
Using Blended Learning Method: Interactive Websites to Attract Student's Interest in Learning Science
}

\author{
Aida Fikriyah $^{\mathrm{a}, 1}$, Nailil Inayah ${ }^{\mathrm{a}, 2}$, Bayu Sandika ${ }^{\mathrm{b}, 3}$, Rindah Permatasari $^{\mathrm{a}, 4}$ \\ ${ }^{a}$ Postgraduate Program, Universitas Negeri Surabaya, Ketintang, Surabaya 60231, Indonesia \\ ${ }^{\mathrm{b}}$ Postgraduate Program, Universitas Airlangga, Mulyorejo, Surabaya 60115, Indonesia \\ 1'aidafikriyahh@gmail.com, ${ }^{2}$ inayahnaili189@gmail.com, ${ }^{3}$ bayusandika@gmail.com, ${ }^{4}$ rindahpermatasari@gmail.com
}

\begin{abstract}
The 2013 curriculum in Indonesia encourages educators to provide technology embedded learning activities. Blended learning is a learning method that combines face-to-face activity and ICT-based learning through several learning sources from internet in order to assist pupils to learn certain topics easily. This learning method can provide great effective experiences for learners by combining the different learning environments. The websites addressed which serve as knowledge sources in the blended learning method are http://www.brainpop.com/ and http://www.bbc.co.uk/. Those websites provide videos, games, and explanations about science that motivate students to learn and to comprehend a topic. They also contain well-developed pictures, three-dimensional models, animations and interactive environments that attract learner's motivation. They are expected to be able to assist teachers facilitate students interactively. This study aims at seeing the student's interest to learn science through the use of those two websites in the blended learning method. This descriptive research was conducted toward 10 students at 8 Grade of SMPN 12 Surabaya in June 2014. The participants were asked to fill out the questionnaires to analyze the data on student's motivation to learn science during the class. Each student responded toward the two websites that were used in this blended learning method. According to the result of the questionnaires, every student gave positive responses toward two websites. The average of percentage of student responses toward http://www.brainpop.com/ was $93 \%$; meanwhile the total percentage of student responses toward http://www.bbc.co.uk/ was $89 \%$. Therefore, these data proves that the use of those two websites in the blended learning method was able to attract the student's interest in learning science.
\end{abstract}

Index Terms - Blended learning, 2013 curriculum, website, and student's interest.

\section{Introduction}

In the globalization era, technology develops rigorously to improve the quality of education. Recently, youths should face a great development in society and technology with abundant information and products of technology, and educational system should facilitate them to be an active user. Curriculum as one of important components in education contributes a lot to broaden the quality of learning activities at schools. The 2013 curriculum aims at preparing the youths to have abilities as Indonesian citizens who are productive, creative, and good in attitudes [1].

According to this curriculum, the learning activities employ scientific and inquiry approaches, student-centered, and technology-based activities [1]. Teachers do not have to be the main learning sources for the students. Students are able to obtain knowledge from any learning sources, such as printed media or technology-based media which are appropriate to the learning objectives.
The traditional teacher-centered learning approach often favors passive reception of knowledge. Students are not active in attaining concepts that they should learn. In contrast, the interactive technology-based teaching encourages active learning since technology has been identified as a critical role in enhancing teaching and learning processes, creating a center of student's attention to learn, and improving their achievements [2].

Blended learning method can be an alternative to create an interactive technology-based teaching. Blended learning is the combination of the traditional teacher-centered learning approach with interactive technology-based teaching. This method is conducted by integrating technology-based learning sources and face-to-face sessions to learn a particular topic easily [3]. By implementing this method, teachers should find a combination of the most sufficient learning sources which are appropriate to the content and to the learning objectives [4]. Blended learning is flexible and able to bring a comfortable condition for learners in the learning environment, increase their performance, and develop the good-quality interactions between teachers and students or among students [5].

Educators are able to provide a plenty of technologybased or web-based learning sources for their learning processes through blended learning method. The websites addressed, which are http://www.brainpop.com/ and http://www.bbc.co.uk/, contain animations, videos, pictures, games, explanations, tasks, and quiz about science. Those websites are expected to be able to attract the learner's motivation and to assist learners to comprehend the topics. Those learning sources are appropriate for students in junior and senior high schools.

Through the blended learning method and those websites, it is expected that students will have an ability to define, access, manage, and communicate by using ICT (Information Communication Technology). It has been found that when learners are able to learn themselves, they will be easily processing information. This study aims at seeing the student's interest to learn science through the use of those two websites in the blended learning method.

\section{Review of Related Literatures}

A. Blended learning method

Blended learning has been defined as the combination of technology-based learning and face-to-face activity which is a method of providing many options for learners to acquire knowledge and increase what they have learned [2]. Blended learning method can be stated as a method of 
combining instructional modalities, instructional methods, or online and face-to-face instruction. There are two types of this method, the traditional face-to-face learning environment, and the distributed learning environment using ICT [5].

This method gives many chances for students to explore themselves in discovering and solving the problems in the class through browsing or searching information from ICT-based learning sources, such as; websites and journals [6]. In this method, the teachers are not the only learning source but they also act as the facilitator for the learners and guide them to acquire the knowledge and to comprehend the topic that they learn [7].

All in all, blended learning method is suitable to be implemented in classes as it is beneficial to improve the student's motivation in learning sciences because it uses ICT-based learning sources, such as; websites that provide interactive environments for students in learning a certain topic.

\section{B. Supported theories of blended learning method}

A review of the literature suggests that three learning theories support the blended learning method [8]:

1) Cognitive learning theory: this theory emphasizes the learner's schema as an organized knowledge structure [9]. The cognitive experts recognize that the human mind is not a passive recipient of knowledge. The cognitive perspective of learning refers to mental activity, such as analytical reasoning and critical thinking. If learners are able to understand the connections between concepts, they will break down information and rebuild it with logical connections, and then their understanding will increase, respectively [10].

2) Constructivist learning theory: this theory emphasizes knowledge as a constructed unit made by learners through a learning process. It requires learners to demonstrate their skills by constructing their own knowledge when solving real-world problems. Therefore, the learners are assumed to learn better when they are forced to explore and discover knowledge themselves [11].

3) Socially situated learning theory: this theory emphasizes a correction to constructivism, in which learning is disconnected from the social context. A learning process occurs as learners exercise, test, and improve their knowledge through discussion, dialogue, collaboration, information sharing, and interaction with others [11].

\section{Student motivation to learn}

In the classroom context, the concept of student motivation is used to explain the level of students' attention to learn particular topics that the teachers are explained and taught [12]. Motivating students to learn is one of the greatest challenges that the instructors should face and do. Teachers have to create an optimal classroom environment that is conducive for the learners to learn [13].

Instead of conducting the traditional activities, teachers can incorporate academic activities that get students to actively participate in the class. In addition, these activities allow for more immediate feedback through a combination of face-to-face activities with the use of technology resulted in student's interactions, an opportunity to practice new acquired skills and minimize passive observation [12].

In the learning process, when teachers want to stimulate students' motivation to learn certain topics, they need to encourage students to use their thoughtful information-processing and skill-building strategies during the study. This is quite different from merely offering them incentives for good performance later [14].

\section{Nature of science teaching}

The term science comes from the Latin scientia which means knowledge. Science is a way of knowing or values and beliefs inherent to the development of scientific knowledge [15]. Science is also characterized by the systematic gathering of information through various forms of direct and indirect observations and the testing of this information by methods including, but not limited to experimentation [16].

Furthermore, scientists are ought to tend to be skeptical and apply self-checking mechanisms such as peer review in order to improve objectivity. [16]. The application of learning science aims at enhancing students' subsequent learning of science subject matter, decision-making on scientifically based personal and social issues, and giving students a better understanding of science as a discipline [17].

\section{E. Information, Communication, and Technology-based learning}

Information, Communication, and Technology (ICT) is defined as a diverse set of technological tools and resources used to communicate, create, disseminate, store, and manage information [18]. ICT in the context of student literacy also can be defined as technologies used for accessing, gathering, manipulating, and presenting or communicating information [19].

The positive effect of using ICT is that ICT is a potentially powerful tool for extending educational opportunities, both formal and non-formal [17]. The use of technology is recognized as a powerful mean to enhance a learning process. Teachers should use computers and optimize a technology to support their teaching process in their subjects to grades and areas [20].

\section{F. Empirical supports: the correlation of using blended learning model toward learning motivation}

Several studies reported that students are actively engaged in learning processes when they are strongly motivated. There was an improvement in learning motivation of the students who were taught using blended learning method better than who were taught using traditional talk and chalk method [21].

Blended learning trains students to be independent and active during the process of teaching and learning. Thus, learning can be effective and efficient [22]. Moreover, motivation is a potential energy promoting action. This model was used to gain students motivation and there was a 
significant increase in learning motivation due to the use of blended learning model [23].

The learning processes also should be able to gain students intrinsic motivation by facilitating student interest and supporting their competencies development [11]. Besides implementing this model to increase student's external motivation, teachers should be able to encourage students developing their intrinsic motivation continually.

\section{Research Methods}

This is a descriptive research conducted in June 2014. Ten students consisting of three boys and seven girls at 8 Grade of SMPN 12 Surabaya, aged 13 to 14 years with same education background participated in this study. The students were chosen randomly. All of participants were taught for two learning hours with same topic about science and same learning objectives using blended learning method. The students were encouraged to discuss given problems with their group mates. Then, they were invited to look for information and knowledge from two websites to solve the problems. In this learning activity, they were introduced to use ICT-based learning sources to support their study. Each group of students was observed during the learning activity. At the end of the class, they were asked to fill out the questionnaires. These questionnaires were used to analyze the data about student's motivation to learn science during the class. Each student responded toward the two websites that were used in the blended learning method.

\section{Results and Discussion \\ a) Results}

The websites used as learning sources in the blended learning method for the students in this study were http://www.brainpop.com/ and http://www.bbc.co.uk/. The first website, http://www.brainpop.com/ discusses seven subjects; Science, English, Math, Social Science, Engineering and Technology, Health, Art, and Music. In this study, the researchers only discussed science. This website provides explanations about several topics in science, attractive videos, figures, games, learning tasks, questions and answers, quiz, and other related information that can assist students to learn science easily. There are also lesson ideas for the educators that can guide them prepare their classroom activities (Table 1).

Table 1 The components of http://www.brainpop.com/

\begin{tabular}{|c|c|c|c|}
\hline Number & Figure & Information \\
\hline 1. & The front \\
& & menu contains \\
several \\
subjects. \\
Students can \\
choose the \\
subject they \\
will learn.
\end{tabular}

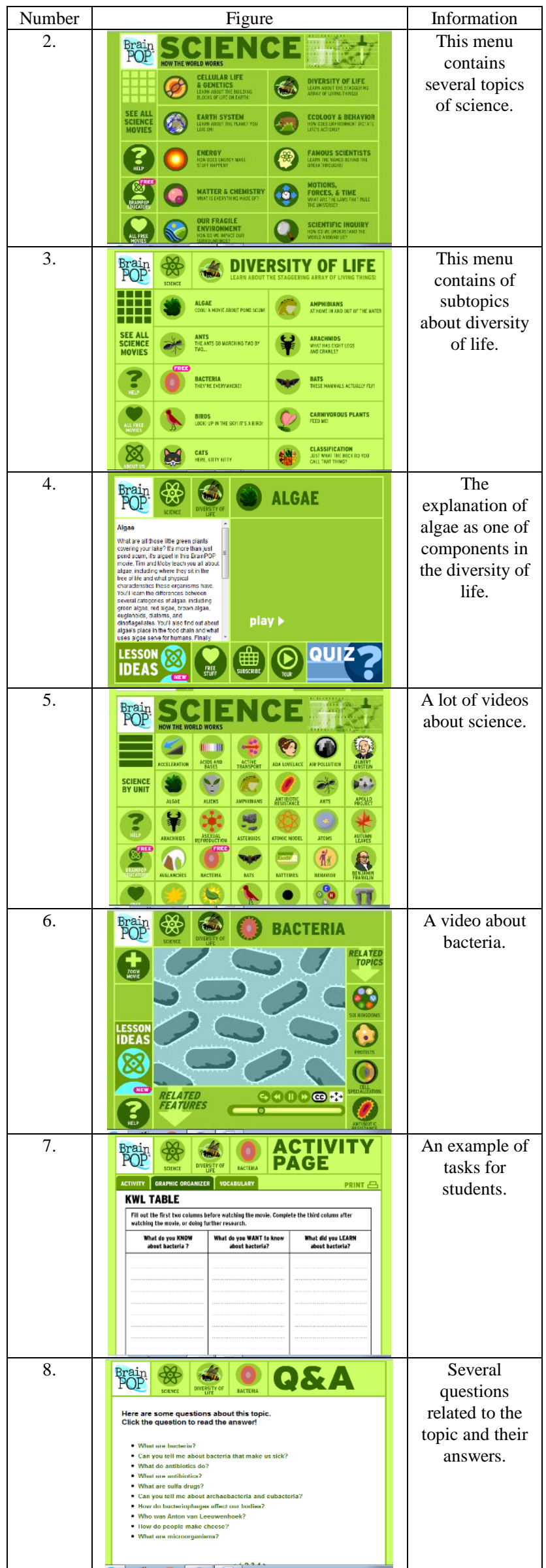




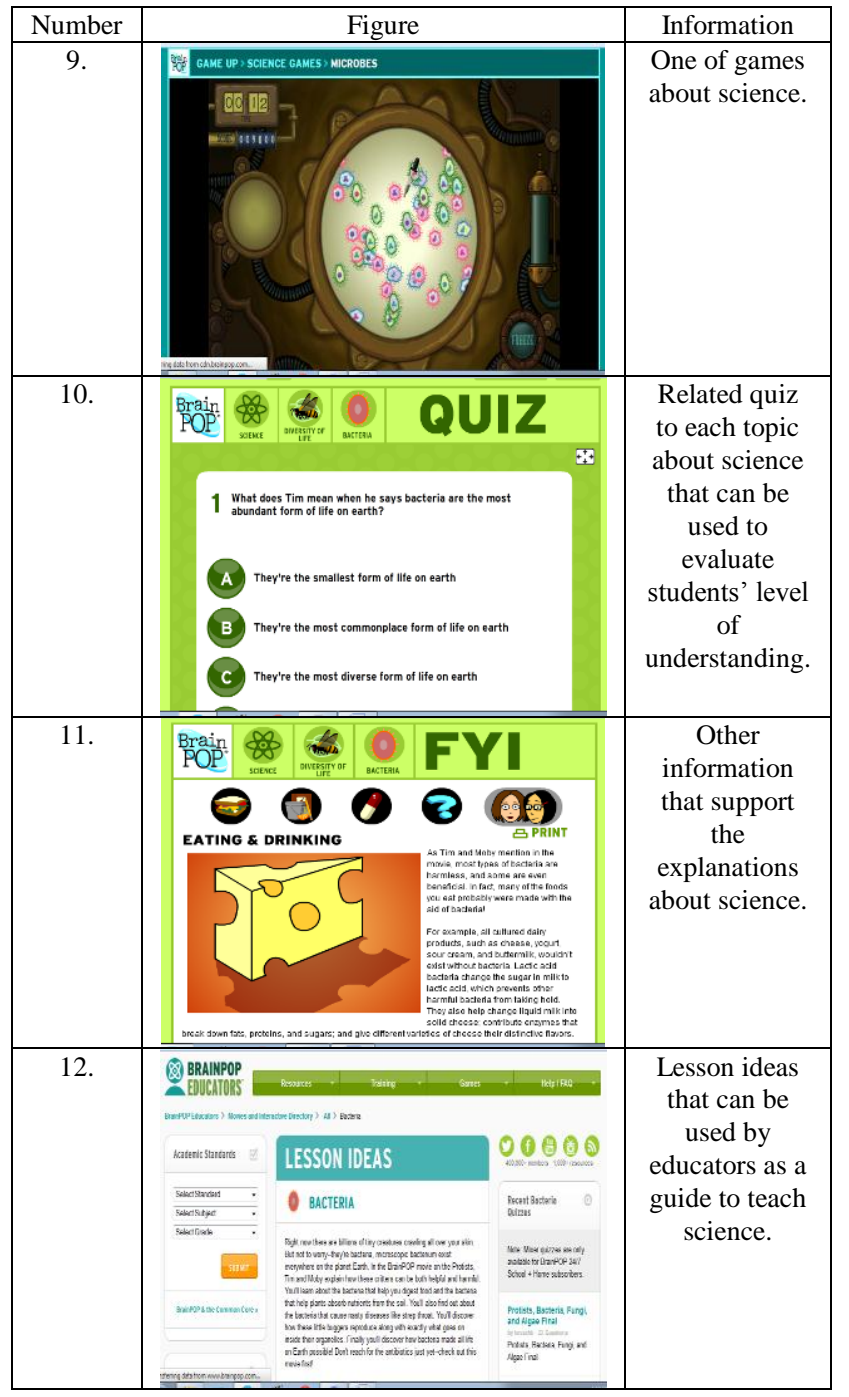

The second website, http://www.bbc.co.uk/ used in this study contains a lot of well-developed pictures, news, videos, questions, games, and information related to science that also helped students better understand science (Table 2).

Table 2 The components of http://www.bbc.co.uk/

\begin{tabular}{|c|c|c|}
\hline Number & Figure & Information \\
\hline 1. & 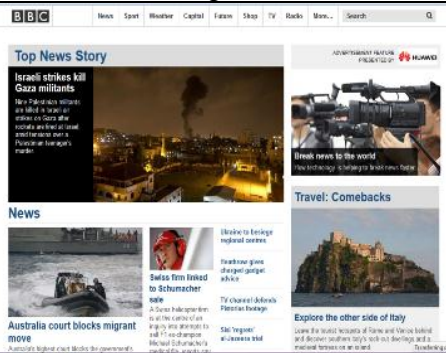 & $\begin{array}{c}\text { The front } \\
\text { menu. }\end{array}$ \\
\hline 2. & Science & $\begin{array}{c}\text { Related } \\
\text { news about } \\
\text { science. }\end{array}$ \\
\hline
\end{tabular}

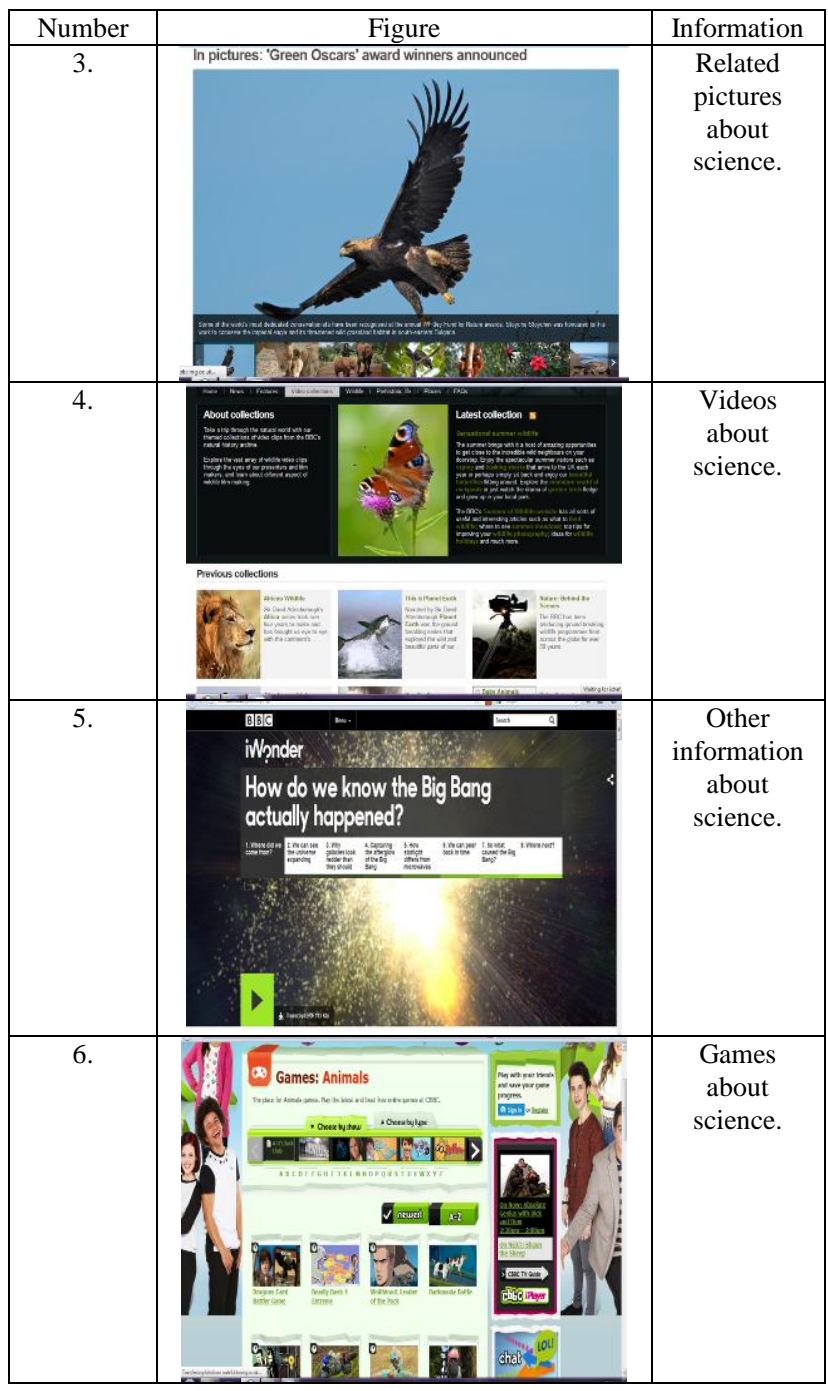

According to the student's response sheets, every student gave positive responses toward the two websites. The average of percentage of student's response toward http://www.brainpop.com/ was $93 \%$ (Table 3); meanwhile the total percentage of student's response toward http://www.bbc.co.uk/ was $89 \%$ (Table 4).

\section{b) Discussion}

The questionnaires that have been filled out by participants in this study were used to find out whether the students are interested to learn science through the blended learning method or not. The questionnaire sheets represented the aspects of clarity, attractiveness, easiness and implementation. Based on the result of questionnaires, the average percentage of the websites http://www.brainpop.com/ and http://www.bbc.co.uk/ were $93 \%$ and $89 \%$, respectively.

Based on the attractiveness aspect, the percentages were 80 to $100 \%$. The attractiveness was related to student's motivation. The more attractive the media are used, the more motivated the students are. However, motivation is a complex psychological factor. Intrinsic motivation is the strongest factor in the learning process [23]. The intrinsic incentive/motivation is also defined as an aspect of an activity that people enjoy and therefore can find a motivation. 
Thus, classroom instruction should enhance student's intrinsic motivation as much as possible [24].

However, much of what topic must be learned in school is not inherently interesting or useful to most students in the short run, so that intrinsic motivation is not easy to be obtained. Even more, in particular, students' intrinsic motivation generally declines from early elementary school through secondary school [24].

Table 3 Student responses toward http://www.brainpop.com/

\begin{tabular}{|c|c|c|}
\hline Number & Questions & $\begin{array}{l}\text { Percentage of } \\
\text { answer "Yes" }\end{array}$ \\
\hline \multicolumn{3}{|c|}{ Clarity and attractiveness } \\
\hline 1. & $\begin{array}{l}\text { Are you interested to learn science } \\
\text { through this website? }\end{array}$ & $100 \%$ \\
\hline 2. & $\begin{array}{l}\text { Are the figures in this website clear } \\
\text { and attractive? }\end{array}$ & $100 \%$ \\
\hline 3. & $\begin{array}{l}\text { Are the videos in this website clear } \\
\text { and attractive? }\end{array}$ & $100 \%$ \\
\hline 4. & $\begin{array}{l}\text { Has the menu in this website } \\
\text { accommodate your need in learning } \\
\text { science? }\end{array}$ & $80 \%$ \\
\hline 5. & $\begin{array}{l}\text { Is your motivation to learn science } \\
\text { through this website much more than } \\
\text { before? }\end{array}$ & $100 \%$ \\
\hline \multicolumn{3}{|c|}{ Level of difficulty } \\
\hline 6. & $\begin{array}{l}\text { Are the sentences in this website easy } \\
\text { to understand? }\end{array}$ & $80 \%$ \\
\hline 7. & $\begin{array}{l}\text { Is the language of this website easy to } \\
\text { understand? }\end{array}$ & $80 \%$ \\
\hline 8. & $\begin{array}{l}\text { Is the explanation about science in this } \\
\text { website easy to comprehend? }\end{array}$ & $90 \%$ \\
\hline \multicolumn{3}{|c|}{ Implementation } \\
\hline 9. & Is this learning activity new for you? & $100 \%$ \\
\hline 10. & $\begin{array}{l}\text { Can this learning activity be applied } \\
\text { to other topics? }\end{array}$ & $100 \%$ \\
\hline & The average of percentage $=$ & $93 \%$ \\
\hline
\end{tabular}

Hence, teachers have to exert to enhance their students' interest in the material that they present. This can be facilitated through media or websites and blended learning method in order to obtain their intrinsic motivation [6]. By creating an enjoyable and engaging learning process, teachers are able to arouse and maintain the students' interest as well as increase their motivation. Likewise, this learning process enables students to set their own goals and develop their self-actualization [7].

In this study, researchers who acted as teachers were able to stimulate the student's learning motivation through the interactive environments using the blended learning method. Students learned science by themselves. In the learning process, when teachers wanted to stimulate students' motivation to learn certain topics, they needed to encourage students to use their thoughtful informationprocessing and skill-building strategies when they were studying [13].

All participants also argued that this learning method was able to motivate them in learning science much more than the learning processes before. The learning process should be enjoyable and capable of attracting student's interest in learning a particular topic because when students are interested to learn, then they will comprehend much more topics than when they are less likely to motivate [25].
The learning processes also should be able to enhance student's intrinsic motivation by connecting student's interest and supporting their competencies development. Besides implementing instructional model to enhance extrinsic motivation, teachers are ought to try to develop intrinsic motivation continuously [11].

In addition, the learning activity done by participants in this study also fulfilled the learning theories in which students acted as active recipients of knowledge, according to cognitive learning theory [9]. As the constructivist learning theory stated that the learners are assumed to learn better when they are forced to explore and discover knowledge themselves [11]. Then, they also improved their knowledge through discussion, dialogue, collaboration, information sharing, and interaction with others which is appropriate to the socially situated learning theory [11].

Table 4 Student responses toward http://www.bbc.co.uk/

\begin{tabular}{|c|c|c|}
\hline Number & Questions & $\begin{array}{l}\text { Percentage of } \\
\text { answer "Yes" }\end{array}$ \\
\hline \multicolumn{3}{|c|}{ Clarity and attractiveness } \\
\hline 1. & $\begin{array}{l}\text { Are you interested to learn science } \\
\text { through this website? }\end{array}$ & $80 \%$ \\
\hline 2. & $\begin{array}{l}\text { Are the figures in this website clear } \\
\text { and attractive? }\end{array}$ & $80 \%$ \\
\hline 3. & $\begin{array}{l}\text { Are the videos in this website clear } \\
\text { and attractive? }\end{array}$ & $100 \%$ \\
\hline 4. & $\begin{array}{l}\text { Has the menu in this website } \\
\text { accommodate your need in learning } \\
\text { science? }\end{array}$ & $100 \%$ \\
\hline 5. & $\begin{array}{l}\text { Is your motivation to learn science } \\
\text { through this website much more than } \\
\text { before? }\end{array}$ & $80 \%$ \\
\hline \multicolumn{3}{|c|}{ Level of difficulty } \\
\hline 6. & $\begin{array}{l}\text { Are the sentences in this website easy } \\
\text { to understand? }\end{array}$ & $80 \%$ \\
\hline 7. & $\begin{array}{l}\text { Is the language of this website easy to } \\
\text { understand? }\end{array}$ & $80 \%$ \\
\hline 8. & $\begin{array}{l}\text { Is the explanation about science in this } \\
\text { website easy to comprehend? }\end{array}$ & $90 \%$ \\
\hline \multicolumn{3}{|c|}{ Implementation } \\
\hline 9. & Is this learning activity new for you? & $100 \%$ \\
\hline 10. & $\begin{array}{l}\text { Can this learning activity be applied } \\
\text { in other topics? }\end{array}$ & $100 \%$ \\
\hline \multicolumn{2}{|c|}{ The average of percentage $=$} & $89 \%$ \\
\hline
\end{tabular}

The level of difficulty aspect in sentences, language and explanation reached $80 \%$. In other words, the websites do not fully provide an ease. Easiness itself is not enough to maintain motivation, however small challenges are important as well. According to the expectancy theory, under certain circumstances an overly high probability of success can be detrimental to motivation [26].

Furthermore, there is a relationship between probability of success and incentive value of success. Therefore, a success in an easy task is not as valued as a success in a difficult task. Therefore, motivation reaches a maximum point at moderate level of probability of success. Other research findings indicate that moderate to difficult tasks are better for learning and motivation than easy ones [24].

The most important implication of expectancy theory is the common sense proposition of tasks for students should be neither too easy nor too difficult. If students believe that the websites features are too easy, then their motivation will 
not reach maximum. And similarly, if some students feel that the sites are too difficult, their motivation will decrease. Thus, the percentage of easiness should be proportional [13].

As for clarity and implementation aspects that got $100 \%$ percentage response from participants, it showed that the websites were clear to be accessed by students and easy to comprehend. If the websites is clear, students can acquire the knowledge themselves and comprehend the topic that they learn easily [14]. Hence, the websites can be categorized into good learning sources because they use clear sentences and are understandable [27].

The aspect of linguistic got only $80 \%$ because some students argued that they had hard time to understand the English content. Those students got difficulties in the language aspect because they had a little knowledge about vocabulary. Nonetheless, the teachers had to encourage them to always learn every particular topic in English. However, most students also argued that the language of the websites was easy to comprehend. The good learning sources or media have to use clearly and well-comprehend language [28].

Ultimately, students were intrinsically motivated when they found that this learning activity was new for them. Naturally, something that newly learned will enhance their curiosity and get them involved more in the activity. By using this method, student's interest in learning increased as well as their motivation enhanced [29].

The result of questionnaire also showed that the students agreed that the blended learning method can be implemented to another topic because this learning method gave student's opportunities to solve problems themselves through browsing or searching information from the websites as one of ICT-based learning sources. In this learning method, the teacher guided them to acquire the knowledge and to comprehend the topic that they learn [7].

All in all, the blended learning method with the two websites in this study is recommended to be applied to any classes because it can attract student's interest in learning particular topics.

\section{Conclusion}

It can be concluded that the use of those two websites in the blended learning method was able to attract the student's interest in learning science, showed by the result of student's responses, 93\% toward http://www.brainpop.com/ and $89 \%$ toward http://www.bbc.co.uk/.

\section{Acknowledgments}

A great appreciation is given to Prof. Mohammad Nur for the guidance and suggestions he has provided during this research. We would also like to thank to all the 8 Grade students of SMPN 12 Surabaya who participated in this research. In particular, we would like to express our gratitude to Director of Postgraduate Program and English lecturers at Universitas Negeri Surabaya for their support and encouragement in writing our research.

\section{References}

[1] Kurikulum 2013. Kementerian Pendidikan dan Kebudayaan Republik Indonesia, 2013.
[2] F. Aladejana, "Blended learning and improved biology teaching in the Nigerian secondary schools," Proceedings of the World Congress on Engineering and Computer Science, San Francisco, 2008.

[3] İ-Ü. Yapici, and H. Akbayin, "The effect of blended learning model on high school students' biology achievement and on their attitudes towards the internet," The Turkish Online Journal of Educational Technology, vol. 11, issue 2, pp. 228-237, April 2012.

[4] J. R. Young, "Hybrid teaching seeks to end the divide between traditional and online instruction," The Chronicles of Higher Education, vol. 48, no. 28, pp. A33-A34, 2002.

[5] C. R. Graham, Blended Learning Systems, 2005

[6] Rusman, Teknologi Informasi dan Komunikasi dalam Pembelajaran, Bandung: Universitas Pendidikan Indonesia, 2009.

[7] D. S. Marco, Blended Learning of Face to Face TeachingPreferences of Estonian Students, 2009.

[8] S. Hadjerrouit, "Towards a blended learning model for teaching and learning computer programming: A case study," Informatics in Education, vol. 7, no. 2, pp. 181-210, 2008.

[9] J. Bruner, Acts of Meaning, Cambridge: Harvard University Press, 1990.

[10] E. Gagne, C. Yekovich, and F. Yekovisch, The Cognitive Psychology of School Learning (2nd ed.), New York: HarperCollins, 1993.

[11] R. E. Slavin, Educational Psychology Theory and Practice, Fifth Edition, Boston: Allyn and Bacon, 1997.

[12] H. Davis, "The quality and impact of relationships between elementary school children and teachers," Contemporary Educational Psychology, vol. 26, pp. 431-453, 2001.

[13] J. Brophy, Motivating Students to Learn, Second Edition, London: Lawrence Erlbaum Associates, Publisher, 2004.

[14] M. Ford, Motivating Humans: Goals, Emotions, and Personal Agency Beliefs, Newbury Park, CA: Sage, 1992.

[15] N. G. Lederman, "Nature of science: Past, present, and future," AsiaPacific Forum on Science Learning and Teaching, vol. 7, issue 1, foreword, p.2, 2006

[16] National Science Teachers Association (NSTA), "Position Statement: The Nature of Science," 2000.

[17] F. Abd-El-Khalick, "Developing deeper understandings of nature of science: the impact of a philosophy of science course on preservice teachers' views and instructional planning," International Journal of Science Education, vol. 27, no. 1, pp. 15-42, 2005.

[18] United Nations Educational, Scientific and Cultural Organization, "New Directions of ICT - Use in Education," 1999.

[19] Ministerial Council on Employment, Education, Training and Youth Affairs Performance Measurement and Reporting Taskforce, "National Assessment Program, Information and Communication Technology Literacy 2008, Years 6 and 10, An Assessment Domain for ICT Literacy". 2008.

[20] Aktaruzzaman, Md. R. H. Shamim, C. K. Clement, "Trends and issues to integrate ict in teaching learning for the future world of education," International Journal of Engineering \& Technology, IJET-IJENS, vol. 11, no. 03, pp. 114-119, 2011.

[21] S. B. Sjukur, "Pengaruh model blended learning terhadap motivasi dan prestasi belajar siswa tingkat SMK," vol. 2, no. 3, June 2012.

[22] Hermawanto, S. Kusairi, dan Wartono, "Pengaruh blended learning terhadap penguasaan konsep dan penalaran fisika peserta didik kelas X," Jurnal Pendidikan Fisika Indonesia, vol. 9, pp. 67-76, January 2013.

[23] I. Syarif, "Pengaruh model blended learning terhadap motivasi dan prestasi belajar siswa SMK," Jurnal Pendidikan Vokasi, vol. 2, no. 2, pp. 234-249, July 2012.

[24] R. I. Arends, Learning to Teach, Ninth Edition, New York: McGrawHill, 2012.

[25] D. Ahimsa, Cara Belajar Cepat Abad XXI, Bandung: Nuansa, 2002.

[26] A. Woolfolk, Educational Psychology, Eleventh Edition, New Jersey: Pearson Education International, 2010.

[27] Asra dan Sumiati, Metode Pembelajaran, Bandung: Wacana Prima, 2007.

[28] T. Nurseto, "Membuat media pembelajaran yang menarik," Jurnal Ekonomi dan Pendidikan, vol. 8, no. 1, pp. 1-15, 2011.

[29] Rosmiati, "Pengembangan perangkat pembelajaran blended learning model kooperatif untuk meningkatkan hasil belajar fisika SMA kelas XI," Jurnal Penelitian Pendidikan Sains Unesa, vol. 2, no. 2, pp. 106-110, 2014. 